\title{
Keterampilan Motorik Kasar Anak Usia Dini Ditinjau Dari Jenis Kelamin
}

\author{
Dinita Vita Apriloka \\ Pendidikan Islam Anak Usia Dini UIN Sunan Kalijaga Yogyakarta \\ Jl. Marsda Adisucipto Yogyakarta \\ Email:dinitavitaa@gmail.com
}

Naskah diterima: 15 Desember 2019, direvisi: 20 Maret 2020, diterbitkan: 31 Maret 2020

\begin{abstract}
Abstrak
Keterampilan Motorik merupakan jasmani melalui kegiatan pusat syaraf, urat syaraf dan otot yang terkoordinasi yang sangat penting dalam pertumbuhan dan perkembangan anak usia dini, sehingga melatih atau membiasakan keterampilan motorik kasar anak melalui permainan kreatif merupakan tahapan dalam mendukung tumbuh kembangnya. Namun, terkadang yang terjadi saat ini motorik kasar anak kurang terlatih. Oleh karena itu penelitian ini bertujuan untuk mengetahui perkembangan saat ini dalam keterampilan motorik kasar anak yang ditinjau berdasarkan jenis kelamin. Metode penelitian yang digunakan adalah PreEksperiment Design dengan desain penelitian One Group Pretest Posttest Design. Penelitian ini dilakukan di PAUD Khoerul Anwar dengan populasi sebanyak 12 siswa pada kelas A. Berdasarkan hasil penelitian dan melakukan uji hasil penelitian menunjukan bahwa keterampilan motorik kasar anak usia dini menggunakan permainan kreatif ditinjau dari jenis kelamin pada anak laki-laki dan perempuan tidak terdapat perbedaan.
\end{abstract}

Kata kunci: jenis kelamin, keterampilan motorik kasar, permainan kreatif

\section{Abstract}

Motor skills are physical through coordinated nerve, nerve and muscle center activities that are very important in early childhood growth and development, so training or familiarizing children with gross motor skills through creative play is a stage in supporting their growth and development. However, sometimes what happens when the gross motor skills of children are poorly trained. Therefore this study aims to determine current developments in children's gross motor skills that are reviewed by sex. The research method used was Pre-Experiment Design with One Group Pretest Posttest Design. This research was conducted in PAUD 
Khoerul Anwar with a population of 12 students in class A. Based on the results of the study and conducting research results showed that the gross motor skills of young children using creative games on boys and girls there were no differences.

Keywords: creative games, gender, gross motor skills

\section{Pendahuluan}

Secara terminologi (Basri, 2009:53-53) Pendidikan dapat diartikan sebagai pembinaan, pembentukan, pengarahan, pencerdasan, pelatihan yang ditujukan kepada anak didik secara formal maupun nonformal dengan tujuan membentuk anak didik yang cerdas, berkepribadian, memiliki keterampilan atau keahlian tertentu sebagai bekal dalam kehidupannya di masyarakat. Menurut Undang-Undang Nomor 20 Tahun 2003 tentang Sistem Pendidikan Nasional disebutkan bahwa Pendidikan adalah usaha sadar dan terencana untuk mewujudkan suasana belajar dan proses pembelajaran agar peserta didik secara aktif dapat mengembangkan potensi dirinya untuk memiliki kekuatan spiritual agama, mengendalikan diri, kepribadian, kecerdasan, akhalak mulia serta keterampilan yang diperlukan dirinya, masyarakat, bangsa dan negara. Sesuai dengan Undang-Undang Nomor 20 Tahun 2003 Pasal 1 jenjang Pendidikan adalah tahapan Pendidikan yang ditetapkan berdasarkan tingkat perkembangan peserta didik, tujuan yang akan dicapai, dan kemampuan yang dikembangkan.

Pertumbuhan memiliki perbedaan dengan perkembangan. Pertumbuhan terkait dengan perubahan fisik pada individu, sedangkan perkembangan terkait dengan perubahan psikis pada individu (Wiyani, 2016: 111). Pertumbuhan fisik memberikan pengaruh besar terhadap kemampuan motorik anak. Motorik merupakan perkembangan pengendalian Gerakan tubuh melalui kegiatan yang terkoordinir antara susunan syaraf, otot, otak dan spinal cord. Fisik motorik terbagi menjadi dua yaitu motorik halus dan motorik kasar. Dalam Pendidikan Anak Usia Dini menunjukan perkembangan yang sangat pesat yang perlu dicermati dan dibina agar jelas arah kedepannya. Saat ini, perkembangan ilmu pengetahuan, seni dan teknologi berkembang sangat begitu pesat, seluruh masyarakat terutama di Indonesia menikmati buah karya ilmu pengetahuan, seni dan teknologi ini. Bahkan anakanak sekalipun sudah memanfaatkannya. Tetapi sering kita tidak sadari bahwa Pendidikan yang terjadi pada anak saat ini lebih banyak mengenal dan menghafal dan istilah serta rumusan angka dan simbol-simbol, tanpa memahami makna dan kegunaanya untuk 
kehidupan. Dunia sekolah menjadi kehilangan generasi yang cerdas, kreatif, mandiri dan percaya diri kini telah tergantikan oleh generasi yang milenial dan seterusnya. Sehingga apa yang akan terjadi dengan perkembangan yang muncul adalah generasi yang tidak kreatif terutama dalam pertumbuhan dan perkembangan motorik anak. Sering kita lihat adanya kebiasaan yang menyebabkan anak kurang gerak dalam kesehariannya. Seperti kurangnya lingkungan bermain yang dapat merangsang tumbuh kembang anak dalam melatih motoriknya yang mengakibatkan anak kurang bergerak karena hanya duduk diam di depan televisi, komputer dan alat komunikasi (bandphone).

Dunia anak merupakan dunia bermain terutama dimasa usia saat ini anak lebih bisa menangkap pembelajaran dengan bermain ketimbang belajar yang dirasakan monoton Bermain adalah aktivitas yang angat menyenangkan bagi anak usia dini, bahkan pada anak usia dini sebaiknya dalam kegiatan sekolah menggunakan metode bermain sambal belajar bukan belajar sambal bermain. Dimana bermain diartikan sebagai suatu aktivitas yang langsung, dimana seorang anak berinteraksi dengan orang lain, berbagai benda disekitar, dilakukan dengan senang hati atas inisiatif sendiri, menggunakan daya khayal (imajinasi), menggunakan panca indra, serta seluruh anggota tubuhnya. Bermain (latif, 2014:77) dapat diartikan sebagai setiap kegiatan yang dilakukan untuk kesenangan yang ditimbulkannya dan tanpa mempertimbangkan hasil akhir. Pada dasarnya setiap anak mengalami pertumbuhan dan perkembangan yang meliputi seluruh bagian tubuhnya. Pada hakikatnya Pendidikan anak usia dini (Suyadi, 2013: 17) diselenggarakan dengan tujuan untuk memfasilitasi pertumbuhan dan perkembangan anak secara menyeluruh atau menekankan pada pengembangan seluruh aspek kepribadian anak.karena pertumbuhan anak usia dini berlangsung sangat cepat, sehingga merupakan kesempatan ideal bagi anak untuk belajar mengembangkan potensi yang ada pada dirinya. Selain itu tujuan Pendidikan (Vera, 2012: 21-25) yang ingin dicapai melalui aktivitas belajar di luar ruang atau di lingkungan sekolah untuk mengarahkan anak untuk mengembangkan bakat dan krativitas mereka, meningkatkan kesadaran, apersepsi dan pemahaman anak terhadap lingkungan, menunjang keterampilan dan ketertarikan anak, memberikan kesempatan pada anak dalam perubahan prilaku melalui penataan latar pada kegiatan, dan menyediakan waktu seluas-luasnya untuk belajar dari pengalaman

Perkembangan motorik merupakan salah satu aspek pertumbuhan anak yang begitu jelas dan terlihat, kadang-kadang kita menerimanya begitu saja. Peneliti mengamati bahwa 
kurang terlatihnya keterampilan motorik kasar anak usia dini, pada permasalahan ini peneliti mencoba mengamati bahwa keterampilan motorik kasar anak yang ditinjau dari jenis kelamin anak laki-laki dan anak perempuan dalam permainan kreatif di PAUD Khoerul Anwar. Dalam permainan ini bertujuan untuk mengasah dan meningkatkan keterampilan motorik kasar anak usia dini. karena, permainan ini untuk melatih keterampilan motorik kasar anak usia dini bermanfaat untuk mengembangkan banyak aspek pertumbuhan dan perkembangannya. Selain itu faktor umum yang dapat mempengaruhi perkembangan anak usia dini berdasarkan jenis kelamin (Desmita, 2009: 32-33) memegang peranan yang penting dalam perkembangan fisik motorik dan psikis anak usia dini. Dalam hal ini anak yang baru lahir misalnya, anak laki-laki sedikit lebih besar daripada anak perempuan, tetapi kemudian anak perempuan tumbuh lebih cepat daripada anak laki-laki, dalam hal kematangan juga demikian, anak perempuan lebih dahulu matang daripada anak laki-laki.

\section{Metodologi}

Metodologi penelitian (Sugiyono, 2017:74) yang digunakan dalam penelitian ini adalah Pre-Exsperiment Design. Karena desain ini belum merupakan eksperimen sungguhsugguh. Karena, masih tedapat variable luar yang ikut berpengaruh terhadap terbentuknya variable dependen. Jadi hasil eksperimen yang merupakan variable dependen itu bukan semata-mata dipengaruhi oleh variable independen. Hal ini dapat terjadi, karena tidak adanyan variable kontrol dan sampel tidak dipilih secara random. Dalam desain ini melibatkan satu kelompok yang diberi post-test. permainan kreatif di PAUD Khoerul Anwar menggunakan bentuk One-Group Pretest-Posttest Design. Instrumen yang digunakan sebagai posttes merupakan instrumen untuk mengukur keterampilan motorik kasar anak usia dini yang berjumlah 12 siswa pada kelas A di PAUD Khoerul Anwar. Pemilihan sempel dilakukan purposive karena peneliti bertujuan untuk membandingkan keterampilan motorik kasar melalui permalinan kreatif untuk anak usia dini yang ditinjau dari jenis kelamin.

Teknik pengumpulan data dengan melakukan observasi dan dokumentasi dimana observasi dengan melakukan pengamatan melalui instrumen keterampilan motorik kasar anak usia dini dan analisis data yang digunakan melalui pendekatan kuantitatif yang diperoleh dari bermain kreatif siswa terhadap keterampilan motorik kasar anak usia dini. Bahwa hasil perlakuan dapat diketahui lebih akurat, karena dapat membandingkan dengan keadaan sebelum diberi perlakuan (Sugiyono, 2017: 74). Selanjutnya analisis logis 
merupakan suatu tes yang telah dilakukan penganalisisan secara logika dan ternyata memiliki daya ketepatan mengukur disebut tes yang telah memiliki validitas logis atau validitas rasional (Hayati, 2013:109).

\section{Hasil dan Diskusi}

Data tentang keterampilan motorik kasar anak usia dini pada permainan kreatif yang diperoleh dari pengisian lembar observasi yang terdiri dari 8 indikator sesuai Peraturan Menteri Pendidikan dan Kebudayaan Republik Indonesia Nomor 137 Tahun 2014 tentang Standar Nasional Pendidikan Anak Usia Dini pada aspek keterampilan motorik kasar meliputi: menirukan gerakan binatang, pohon, tertiup angin, pesawat terbang; melakukan gerakan menggantung (bergelayut); melakukan gerakan melompat, meloncat, dan berlari secara terkoordinasi; melempar sesuatu secara terarah; menangkap sesuatu secara tepat; melakukan gerakan antisipasi; menendang sesuatu secara terarah; dan memanfaatkan alat permainan diluar kelas.

Penelitian ini bertujuan untuk memperoleh gambaran keterampilan motorik kasar melalui permainan kreatif anak usia dini yang ditinjau dari jenis kelamin. Data keterampilan motorik diambil setelah siswa menerapkan permainan kreatif dengan guru sebelumnya. Statistik deskritptif skor hasil posttest keterampilan motorik kasar anak usia dini ditinjau dari jenis kelamin tercantum dalam table 1 berikut ini.

Tabel 1.

Statistik Deskriptif Keterampilan Motorik Kasar melalui Permainan Permainan Kreatif

\begin{tabular}{ccccccccc}
\hline \multicolumn{3}{c}{ Perempuan } & \multicolumn{3}{c}{ Laki-laki } \\
\hline $\begin{array}{c}\text { Jumlah } \\
\text { Siswa }\end{array}$ & $\begin{array}{c}\text { Score } \\
\text { Minimal }\end{array}$ & $\begin{array}{c}\text { Score } \\
\text { Maxsimal }\end{array}$ & $\begin{array}{c}\text { Rata- } \\
\text { rata }\end{array}$ & $\begin{array}{c}\text { Jumlah } \\
\text { Siswa }\end{array}$ & $\begin{array}{c}\text { Score } \\
\text { Minimal }\end{array}$ & $\begin{array}{c}\text { Score } \\
\text { Maxsimal }\end{array}$ & $\begin{array}{c}\text { Rata- } \\
\text { rata }\end{array}$ \\
\hline Posttes & 9 & 83 & 95 & 89 & 3 & 83 & 95 & 90
\end{tabular}

Sumber: (Hayati, 2014)

Table 1 menunjukan hasil keteramiplan motorik kasar anak usia dini melalui permainan kreatif yang sudah diberikan perlakuan. Berdasarkan hasil perhitungan, peneliti memperoleh nilai dari uji normalitas memiliki data normal pada laki-laki dan perempuan dan data uji homogenitas memilki variansi homogen. Karena bervariansi homogen dan melakukan uji t dengan sig.(2-tailed) 0,756 lebih besar dari taraf signifikasi 0,5 maka Ho 
diterima, artinya tidak terdapat perbedaan rata-rata antara anak laki-laki dan anak perempuan.

Mengacu pada hasil penelitian, peneliti menemukan bahwa tidak terdapat perbedaan rata-rata keterampilan motorik kasar anak laki-laki dan anak perempuan setelah melakukan permainan kreatif. Menurut (Vera, 2012:27) guru masih enggan mengajak siswa belajar diluar kelas karena berbagai alasan. Mareka hanya mengajak para siswa belajar diluar kelas terkait olahraga saja. Padahal pada kenyataanya melakukan kegiatan pembelajaran diluar kelas dapat melatih keterampilan motorik kasar anak. Sedangkan kenyataannya dari anak laki-laki dan perempuan yang lebih sering terlatih keterampilan motorik kasar nya adalah anak laki-laki karena sering bermain diluar sekolah Bersama dengan temannya yang dapat melatih keterampilan motorik kasarnya. Adapun hambatan yang mempengaruhi keterampilan motorik kasar anak usia dini (Yuantini, 2019: 136) terkait dengan ketidakmampuan anak mengatur keseimbangan reaksi kurang cepat serta koordinasi kurang baik. Ketika anak memasuki jenjang Pendidikan kemampuan bereaksi dan koordinasi juga menentukan keterampilan motorik kasar anak. Hal ini terjadi karena kurang diberi kesempatan untuk berlatih atau ada kemungkinan anak memilki masalah dalam syaraf motoriknya.

Sehingga dari hasil penelitian yang ditinjau dari jenis kelamin untuk keterampilan motorik kasar anak usia dini tidak terdapat perbedaan rata-rata skor antara anak laki-laki dan anak perempuan. perbedaan terletak pada saat anak melakukan aktivitas permainan kreatif, dimana anak laki-laki lebih aktif dan berani dibanding dengan perempuan. Menurut Gallahue dan Ozmun dalam bukunya Understanding Motor Development (1998:209 dalam Widiyanti, 2016) menyebutkan bahwa perekembangan motorik anak memilki fase yang berbeda-beda sesui dengan rentang umur anak, dan akan mengalami kegiatan dan tingkat kesukaran yang berbeda-beda pula. Akan tetapi pada penelitian yang ditinjau dari jenis kelamin tidak terdapat perbedaan yang signifikan karena jumlah anak peremuan dan anak laki-laki yang berbeda.

\section{Penutup}

Keterampilan motorik kasar anak usia dini sangatlah penting dalam mempengaruhi pertumbuhan dan perkembangan anak. Maka dari itu pihak sekolah tidak hanya membiarkan anak bermain saat jam istirahat tapi jam belajarpun melatih keterampilan 
motorik kasar pada anak sangatlah penting dengan berbagai macam permainan yang dapat dikembangkan pada anak. Berdasarkan hasil penelitian tentang keterampilan motorik kasar anak usia dini melalui permainan kreatif PAUD Khoerul Anwar diperoleh simpulan: bahwa keterampilan motorik kasar anak usia dini setelah melakukan penelitian tidak terdapat perbedaan kemampuan keterampilan mototik kasar pada anak laki-laki dan perempuan melainkan memiliki kemampuan yang sama. Hal ini disebabkan karena dalam menentukan konsep tidak memandang jenis kelamin. Namun, yang membedakan terletak pada keterampilan motorik kasar anak melalui permainan kreatif.

\section{Daftar Pustaka}

Basri, H. 2009. Filsafat Pendidikan Islam. Bandung: CV Pustaka Setia

Desmita. 2009. Psikolog Perkembangan Anak Usia Dini. Bandung: Rosda

Hayati. T. 2013. Evaluasi Pemebelajaran. Bandung: CV Insan Mandiri

Hayati. T. 2014. Pengantar Statistik Pendidikan. Bandung: CV Insan Mandiri

Latif, Muchtar, dkk. 2014. Orientasi Baru Pendidikan Anak Usia Dini: Teori dan Aplikasi. Jakarta: Kencana

Peraturan Menteri Pendidikan dan Kebudayaan Republik Indonesia Nomor 137 Tahun 2014 Tentang Standar Nasional Pendidikan Anak Usia Dini.

Sugiyono. 2017. Metode Penelitian Kuantitatif, Kualitatif dan R\&D. Bandung: CV Alfabet

Suyadi, Maulidya Ulfah. 2013. Konsep Dasar PAUD. Bandung: PT Remaja Rosdakarya

Undang-Undang Sistem Pendidikan Nasional Nomor 20 Tahun 2003

Vera, Adelia. 2012. Metode Mengajar Anak Di Luar Kelas. Yogyakarta: DIVA Press

Wiyani, Novan Ardy. 2016. Konsep Dasar PAUD. Yogyakarta: Gava Media

Yuantini, Gustiana, Anas, dkk. 2019. Filsafat Anak Usia Dini. Yogyakarta: Timur Barat 